\title{
AGREEMENT IN DIAGNOSIS OF KNEE INJURIES BY ORTHOPEDISTS WITH CLINICAL EXPERIENCE IN KNEE TREATMENT
}

\section{CONCORDÂNCIA EM DIAGNÓSTICO DE LESÃO DE JOELHO POR MÉDICOS ORTOPEDISTAS ESPECIALISTAS EM JOELHO}

\author{
Thiago Rocha Protta ${ }^{1}$, Lara Guercio dos Santos ${ }^{1}$, Alexandre Kusabara ${ }^{1}$, Diego Philip ${ }^{2}$, Jonas Grispun ${ }^{1}$, Marcelo Schimitd Navarro ${ }^{1}$ \\ 1. Department of Orthopedics and Traumatology, Faculdade de Medicina do ABC, Santo André, SP, Brazil. \\ 2. Hospital Estadual Mario Covas, Santo André, SP, Brazil.
}

\begin{abstract}
Objective: To analyze the level of agreement in diagnosing knee injury among orthopedists with clinical experience in knee treatment. Method: An online questionnaire was used to analyze the ability of orthopedic knee surgeons to diagnose intra-articular knee injuries using MRI, the importance given to this test in their clinical practice, and the agreement between these diagnoses and the radiology report. Results: The study participants considered MRI an important tool for clarifying inconclusive diagnoses and surgical planning. The level of agreement between the surgeons and the radiologist was considered to be very slight for posterior cruciate ligament injuries, collateral ligament injuries, and chondral injuries, and was considered slight for anterior cruciate ligament and meniscus injuries. Conclusion: A diagnosis of intra-articular knee injury must be based on the patient history, physical examination, and radiological imaging (MRI) in order to provide a complete approach to the patient. Level of Evidence III; Clinical study.
\end{abstract}

Keywords: Orthopedics. Magnetic resonance spectroscopy. Knee..

\section{RESUMO}

Objetivo: Analisar o nível de concordância em diagnóstico de lesão de joelho entre médicos ortopedistas com experiência clínica em tratamento do joelho. Método: Um questionário on-line foi usado para analisar a capacidade de o ortopedista cirurgião de joelho diagnosticar lesões intra-articulares de joelho por meio da RM, assim como a importância dada a esse exame em sua prática clínica e a concordância entre os diagnósticos e o laudo do radiologista. Resultados: Os participantes do estudo consideraram a RM um instrumento importante para esclarecer diagnósticos inconclusivos e para planejamento cirúrgico. O nível de concordância entre os cirurgiões de joelho e o radiologista foi considerado muito leve para ligamento cruzado posterior, ligamentos colaterais e lesões condrais e foi considerado leve para as lesões do ligamento cruzado anterior e do menisco. Conclusão: O diagnóstico de lesão intra-articular de joelho deve ser baseado na anamnese, no exame físico e nos exames radiológicos (RM), objetivando a abordagem completa do paciente. Nível de Evidência III; Estudo clínico.

Descritores: Ortopedia. Espectroscopia de ressonância magnética. Joelho.

Citation: Protta TR, Santos LG, Kusabara A, Philip D, Grispun J, Navarro MS. Agreement in diagnosis of knee injuries by orthopedists with clinical experience in knee treatment. Acta Ortop Bras. [online]. 2018;26(1):16-8. Available from URL: http://www.scielo.br/aob.

\section{INTRODUCTION}

Magnetic resonance imaging $(\mathrm{MRI})$ is considered the best test for imaging-based investigation of the knee joint. This is because this technique represents a noninvasive yet accurate option for the evaluation of knee joint pathologies. The diagnosis of knee injuries is directly linked to the clinical history of the patient and careful physical examination. ${ }^{1,2} \mathrm{MRI}$ is usually a type of complementary accurate examination in the assessment of the knee; however, it is costly. 3,4 $\mathrm{MRI}$ is the physical property displayed by the nuclei of certain elements which, when subjected to a strong magnetic field and excited by radio waves at a given frequency, transmit a radio signal that can be captured by an antenna and transformed into an image. 5,6 MRI has greater applicability in the knee than in other joints and provides an excellent diagnosis. It is able to assess lesions of various types, such as ligaments, menisci, tendineae, bone, and chondral lesions. However, there has been no evidence demonstrating that $\mathrm{MRI}$ can reduce the number of negative arthroscopies. ${ }^{7}$

In orthopedics, MRI is one of the main imaging examinations of choice for evaluation of meniscal and knee ligament lesions. ${ }^{6,8}$ The improvement of the imaging technique has assisted orthopedists in closing the diagnosis and taking action in their cases. MRI must be used in accordance with the physical examination and clinical history of the patient. ${ }^{9-11}$

In the orthopedic residence, each service offers a varied range of emphases and guidance regarding the evaluation and importance of magnetic resonance imaging in daily clinical practice. ${ }^{12-14}$ Magnetic resonance imaging is the gold standard for the diagnosis of knee lesions. The objective of this study is to analyze the level of agreement in knee lesion diagnoses by orthopedic doctors with clinical experience on knee treatment.

All authors declare no potential conflict of interest related to this article. 


\section{METHOD}

This is a methodological study.

Twenty orthopedic surgeons will fill out an online questionnaire comprised of multiple choice questions related to the influences of magnetic resonance imaging (MRI) in clinical practice. Ten cases of the most prevalent diseases among the knee pathologies will be shown so that these expert knee surgeons can make their own interpretation of the MRI. The images will be selected by one of the authors, a member of the Brazilian Society of Radiology specializing in the musculoskeletal area, who will report the MRI scans and along with the authors draw up multiple choice questions regarding the diagnosis of these images. The answers will examine the ability of the knee orthopedic surgeons in diagnosing the diseases by means of MRI of the knee. They will also evaluate the importance given to the exam in their practice clinic and the agreement of these results with the radiologist reports.

Patients who are willing to give their images for this work will be informed on the goals and methods and sign an informed consent form, granting researchers the use of their examination results.

The names of the orthopedic doctors who responded to the questionnaires were not disclosed, nor were the answers to these questionnaires, which were not exposed to anyone. With the objective of reducing institutional bias, we counted on the participation of orthopedic doctors with specializations from at least five different institutions. This study was approved by the medical ethics committee of the institution of the Department of Health of Santo André Municipality number 1.744.861.

To describe the responses of doctors and radiologists as well as the profile of the individuals studied, we used absolute and relative frequency. To analyze the agreement in the diagnosis of knee lesions among orthopedists and radiologists, we used the $\kappa$ agreement coefficient (Table 1). The significance level was set at $5 \%$. We used the software Stata 11.0.

\section{RESULTS}

The sample consisted of 20 orthopedists, all with medical residency in the specialty of knee surgery. From these, 18 (90\%) received the title of specialist from the Brazilian Society for Knee Surgery, whereas 8 (40\%) became affiliated over a period of 0 to 5 years.

Among the orthopedists interviewed, 16 (80\%) judged their level of understanding on the analysis of MR images as good/very good, whereas for $55 \%$, the radiologist's report was considered as important/very important.

The majority (60\%) of the sample considered the MRI to be an important test to complement inconclusive clinical diagnoses, and $65 \%$ believed this to be an important test for surgical planning.

In the sample, 10 doctors (50\%) think of the MRI as an examination of average importance in clinical treatment of patients, and 11 (55\%) would change their diagnoses because of MRI results.

Of the orthopedic doctors, 14 (70\%) would disagree with the report of the radiologist on the $\mathrm{MRI}$.

In the sample, 11 doctors (55\%) consider the physical examination more important than the MRI, while 9 (45\%) would submit their patient to the surgical procedure without the MRI examination.

Table 1. Kappa agreement coefficient.

\begin{tabular}{c|c}
\hline \multicolumn{2}{c}{ Kappa coefficient } \\
\hline $\mathrm{k}<0.00$ & inadequate agreement \\
\hline $0.00<\mathrm{k} \leq 0.20$ & very slight agreement \\
\hline $0.21<\mathrm{k} \leq 0.40$ & slight agreement \\
\hline $0.41<\mathrm{k} \leq 0.60$ & moderate agreement \\
\hline $0.61<\mathrm{k} \leq 0.80$ & substantial agreement \\
\hline $0.81<\mathrm{k} \leq 1.00$ & almost perfect agreement \\
\hline
\end{tabular}

We performed the analysis of agreement on the diagnosis of knee lesions among participating orthopedists and radiologists, observing the $\kappa$ index (Table 1). We evaluated lesions in the following structures: anterior cruciate ligament, posterior cruciate ligament, meniscus, collateral ligaments, chondral lesions on the medial femoral condyle, chondral lesions on the lateral femoral condyle, and chondral lesions on the trochlea and patella. (Table 2)

The levels of agreement were statistically relevant items for the anterior cruciate ligament, posterior cruciate ligament, meniscus, collateral ligaments and chondral lesion in the medial femoral condyle $(P<.05)$.

Levels of very slight agreement ( $\kappa: 0.00-0.20)$ were found for the following evaluated structures: posterior cruciate ligament; collateral ligaments; and chondral lesions in the medial and lateral condyle, trochlea, and patella.

Levels of slight concordance ( $\kappa: 0.21-0.40$ ) were found for the following evaluated structures: anterior cruciate ligament and meniscus.

Table 2. Agreement between orthopedists and radiologists

\begin{tabular}{c|c|c|c|c}
\hline Lesion & Agreement & $\begin{array}{c}\text { Expected } \\
\text { Agreement }\end{array}$ & Kappa & $\mathbf{p}^{*}$ \\
\hline Anterior Cruciate Ligament & $55 \%$ & $30.86 \%$ & 0.3491 & 0 \\
\hline Posterior Cruciate Ligament & $45 \%$ & $31.12 \%$ & 0.2015 & 0 \\
\hline Meniscus & $59 \%$ & $37.85 \%$ & 0.3403 & 0 \\
\hline Collateral Ligaments & $46 \%$ & $39.20 \%$ & 0.1118 & 0.0491 \\
\hline Chondral Lesion (medial condyle) & $36 \%$ & $25.80 \%$ & 0.1375 & 0.0004 \\
\hline Chondral Lesion (lateral condyle) & $33 \%$ & $33 \%$ & 0 & 0.5 \\
\hline Chondral Lesion (Troclea/Patella) & $27 \%$ & $23 \%$ & 0.0529 & 0.0631 \\
\hline
\end{tabular}

\section{DISCUSSION}

Currently, MRI plays an important role in the assessment of trauma in the knee by its ability to obtain thin and multiplanar sections with different imaging weights, and being able to identify meniscal, ligament, tendon, and bone lesions. ${ }^{9,13}$

The protocol type used for the study of the knee in MRI is still variable at each institution as the objective is to obtain images with better spatial resolution. An evaluation of the knee is considered suitable by an exam that contains sectional cuts in axial, coronal, and sagittal planes, with weight imaging in $\mathrm{T} 1, \mathrm{~T} 2, \mathrm{DP}$, and $\mathrm{STIR}^{13}$. The accurate diagnosis of knee lesions is directly connected to the clinical history of the patient and a physical examination. The meniscal and ligamentous lesions of this articulation can be evaluated by means of MRI with great applicability when compared with other joints. ${ }^{9}$ However, no evidence has been found that MRI can reduce the number of negative arthroscopies. ${ }^{7,9}$ This explains the results found in our study in which 55\% of the orthopedic doctors consider the physical examination to be the most important thing to diagnose knee's injuries.

A skilled orthopedic surgeon can certainly diagnose ligament and meniscus lesions through physical examination while the MRI is

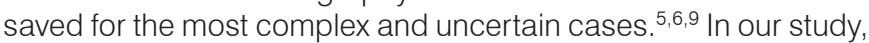
$60 \%$ of knee surgeons would agree with the above, and that the MRI is a complementary diagnostic examination for inconclusive cases. The agreement in classifying the lesions evaluated by the $\kappa$ coefficient in different studies is considered good for anterior cruciate ligament and lateral meniscus lesions, reasonable for the medial meniscus, and low for chondral lesions. ${ }^{5,6}$ The results are in agreement with the literature in which we observed higher concordance in the $\kappa$ coefficient for lesions of the anterior cruciate ligament and meniscus and poor agreement for the chondral lesions.

In the literature, the chondral lesions present low sensitivity and a negative likelihood value greater than 0.5 , thereby reflecting that the 
absence of findings in the MRI do not preclude their existence. ${ }^{4,5,9}$ This explains the low values of the $\kappa$ coefficient found for chondral lesions in this study with statistical significance relevant to the analysis of the chondral lesions in the medial femoral condyle. We did not find in literature other studies comparing the results of $\mathrm{MRI}$ interpretations by more than three doctors. That's may explain why our results had lower agreement between observers. We also used a 1.5 T MRI, but others have used a 3.0 T version.

In Brazil, when doctors indicate a surgery, it's needed to ask authorization for the procedure and implants to the patient's insurance. The insurance uses the MRI report to analyze and authorize it. That may result in some difficulties, for example: if the orthopedic surgeon concludes that patient has an ACL rupture and meniscus tear, he is supposed to be paid for both procedures but if the report from the radiologist doesn't agree with the meniscus tear, the insurance will only pay for $A C L$ reconstruction.

\section{CONCLUSION}

Orthopedic surgeons considered a physical exam to be the main tool to diagnosis knee injuries, followed by clinical history and MRI. The imaging had a greater importance for those cases that were inconclusive after clinical evaluation.

We also conclude that interobserver agreement was slight for ACL and meniscus tears and very slight for PCL, collateral ligaments, and chondral lesions.

AUTHORS' CONTRIBUTIONS: Each author made significant individual contributions to this manuscript. TRP (0000-0003-3610-7152)*: substantial contributions to the concept of the work and analysis and interpretation of the data. MSN (0000-0002-0466-4993)*: work design and final approval of the manuscript version; LGS (0000-0002-1321-7394)*: data collection and analysis and writing; JG (0000-0002-3197-3679)*: AK (0000-0002-9420-8974)*: data collection and analysis and writing; DP (0000-0002-6089-3459)*: statistical analysis. All authors approved the final version of the manuscript. *ORCID (Open Researcher and Contributor ID).

\section{REFERENCES}

1. Magee T, Shapiro M, Williams D. MR accuracy and arthroscopic incidence of meniscal radial tears. Skeletal Radiol. 2002;31(12):686-9.

2. Scholten RJ, Devillé WL, Opstelten W, Bijl D, van der Plas CG, Bouter LM. The accuracy of physical diagnostic tests for assessing meniscal lesions of the knee:a meta-analysis. J Fam Pract. 2001;50(11):938-44.

3. Feller JA, Webster KE. Clinical value of magnetic resonance imaging of the knee. ANZ J Surg. 2001;71(9):534-7.

4. Barry BP. General principles of arthroscopy. In: Terry SC, editor. Campbell operative orthopaedics. 9a . ed. Philadelphia: Mosby Inc; 1999. p. 364-73.

5. Karam FC. A ressonância magnética para o diagnóstico das lesões condrais, meniscais e dos ligamentos cruzados do joelho. Radiol Bras. 2007;40(3):179-82.

6. Brooks S, Morgan M. Accuracy of clinical diagnosis in knee arthroscopy. Ann R Coll Surg Engl. 2002;84(4):265-8.

7. Sanders TG, Miller MD. A systematic approach to magnetic resonance imaging interpretation of sports medicine injuries of the knee. Am J Sports Med. 2005;33(1):131-48.

8. Phelan N, Rowland P, Galvin R, O'Byrne JM. A systematic review and metaanalysis of the diagnostic accuracy of MRI for suspected ACL and meniscal tears of the knee. Knee Surg Sports Traumatol Arthrosc. 2016;24(5):1525-39.

9. Orlando Júnior N, de Souza Leão MG, de Oliveira NH. Diagnosis of knee injuries: comparison of the physical examination and magnetic resonance imaging with the findings from arthroscopy. Rev Bras Ortop. 2015;50(6):712-9.

10. Cunha DL, Ribeiro EJS, Domingues RC. Ressonância magnética da osteonecrose do joelho: estudo de 19 casos. Radiol Bras. 2010;43(2):77-80.

11. Dzoleva-Tolevska R, Poposka A, Temelkovski Z, Samardziski M, Georgieva $D$. The role of clinical diagnosis in meniscal lesions of the knee. Prilozi. 2011;32(1):189-97

12. Kocabey Y, Tetik O, Isbell WM, Atay OA, Johnson DL. The value of clinical examination versus magnetic resonance imaging in the diagnosis of meniscal tears and anterior cruciate ligament rupture. Arthroscopy. 2004;20(7):696-700.

13. De Grossi CM, Marchiori E, Santos AASMD. Comprometimento ósseo do joelho pós-trauma: avaliação pela ressonância magnética. Radiol Bras. 2001;34(3):155-60.

14. Shepard MF, Hunter DM, Davies MR, Shapiro MS, Seeger LL. The clinical significance of anterior horn meniscal tears diagnosed on magnetic resonance images. Am J Sports Med. 2002;30(2):189-92. 